\title{
PENGUNAAN METODE PICTURE AND PICTURE UNTUK MENINGKATKAN PRESTASI BELAJAR SISWA PADA MATERI PENGGOLONGAN HEWAN BERDASARKAN JENIS MAKANAN MATA PELAJARAN IPA KELAS IV SD NEGERI 3 PURWOJATI SEMESTER I TAHUN PEAJARAN 2015/ 2016
}

Oleh:

Taonah

SD Negeri 3 Purwojati Banyumas

\begin{abstract}
ABSTRAK
Masalah yang menjadi fokus perbaikan : (1). Masih rendahnya prestasi pembelajaran siswa pada materi penggolongan hewan berdasarkan jenis makanan; (2). Bagaimana pelaksanaan pembelajaran menggunakan metode picture and picture. Tujuan yang ingin dicapai dalam penelitian ini adalah: (1). Untuk meningkatkan prestasi belajar IPA dengan materi penggolongan hewan berdasarkan jenis makanan bagi siswa kelas IV SD Negeri 3 Purwojati, UPK Purwojati Dinas Pndidikan Kabupaten Banyumas pada semester I Tahun Pelajaran 2015/2016. Penelitian dilakukan melalui proses pengkajian bersiklus yang terdiri dari empat tahapan (perencanaan, pelaksanaan, observasi, dan refleksi) dalam dua siklus perbaikan pembelajaran.

Dari hasil analisis, simpulan yang diperoleh dari penelitian : (1). Belajar; (2). Penggunaan metode picture and picure pada pembelajaran mampu memberikan motivasi siswa sehingga dapat meningkatkan keaktifan siswa dalam proses pembelajaran; (3). Ada kolerasi positif antara keakifan belajar siswa dengan prestasi belajar siswa, semakin tinggi keaktifan siswa, semakin pula keberhasilan siswa dalam pembelajaran, hal ini ditunjukan dari evaluasi siswa yang meningkat yaitu pada pra siklus tingkat ketuntasan siswa mencapai 3 siswa dari 18 siswa 16,7\%, pada siklus I tingkat ketuntasan belajar mencapai 8 siswa yang tuntas dari 18 siswa 44,4\% dan pada siklus II tingkat ketuntasan belajar mencapai 16 siswa dari 18 siswa $88,8 \%$.
\end{abstract}

Kata kunci: Motivasi keaktifan, Prestasi belajar dan Metode picture and picture

\section{Pendahuluan}

Dalam kegiatan belajar mengajar guru harus memiliki strategi agar anak didik dapat belajar efektif dan efisien mengena pada tujuan yang diharapkan. Apabila guru telah menemukan metode yang tepat maka suasana pembelajaran tidak monoton sehingga akan lebih menyenangkan bagi anak didik. Dampak selanjutnya yaitu pada pembelajaran IPA yang berkaitan dengan lingkungan alam sekitar semestinya menyebabkan hasil belajar yang dicapai siswa lebih baik jika dibandingkan dengan mata pelajaran lainnya, karena materi yang disajikan pada pelajaran IPA umumnya berkaitan dengan kehidupan sehari - hari. Namun pada kenyataannya dengan siswa kelas IV SD N 3 Purwojati Kec Purwojati, Ketuntasan belajar yang dicapai pada pelajaran IPA dengan materi pengelompokan hewan masih banyak siswa yang nilainya di bawah kriteria ketuntasan minimal yaitu dengan prosentase hanya 
16,7\% siswa yang memenuhi kriteria ketuntasan. Hal ini menunjukan bahwa hampir separuh dari keseluruhan siswa tidak tuntas belajarnya atau mendapat nilai dibawah KKM yang ditentutakan yaitu 70 .

Berdasarkan pengamatan peneliti, rendahnya ketuntasan yang dicapai siswa disebabkan karena pembelajaran yang cukup monoton cenderung menggunakan metode ceramah dalam memberikan penjelasan. Penerapan metode ini yang selama ini dilakukan kurang menarik bagi siswa, siswa tampak kurang bersemangat dalam belajar, dan sebagian besar siswa kurang aktif dalam mengikuti kegiatan pembelajaran, siswa bosan dan tidak berkonsentrasi dengan materi yang dipelajari. Keadaan ini sangat jauh dari kondisi ideal pembelajaran bahwa siswa harus aktif dan semangat dalam belajar, dan guru dalam proses pembelajaran harus mampu menarik minat siswa untuk belajar. Dengan adanya hal tersebut peneliti bermaksud mengadakan perbaikan melalui penelitian tindakan kelas ( PTK ) dengan metode picture and picture.

Bertolak dari permasalahan diatas, maka masalah dalam penelitian ini dapat dirumuskan sebagai berikut:

1. Bagaimana cara meningkatkan prestasi belajar siswa pada pelajaran IPA tentang materi penggolongan hewan berdasarkan jenis makanan bagi kelas IV SD N 3 Purwojati pada semester I tahun pelajaran 2015/2016?

2. Bagaimana penerapan metode picture and picture dalam meningkatkan belajar IPA tentang materi penggolongan hewan berdasarkan jenis makanan bagi kelas IV SD N 3 Purwojati pada semester I tahun pelajaran 2015/2016?

Dari penyebab-penyebab yang timbul, peneliti mencoba mencari solusi agar proses pembelajaran selanjutnya berkualitas dan selanjutnya merencanakan kegiatan perbaikan pembelajaran. Yang menjadi focus perbaikan pembelajaran adalah “ Bagaimana meningkatkan hasil belajar siswa dalam pembelajaran IPA tentang penggolongan hewan berdasarkan jenis makanannya melalui metode picture and picture ? “

Dalam penelitian meningkatkan minat dan prestasi belajar IPA tentang materi penggolongan hewan berdasarkan jenis makanan menggunakan metode picture and picture pada siswa kelas IV SD N 3 Purwojati Tahun Pelajaran 2015/ 2016 peneliti mempunyai tujuan umum dan tujuan khusus, yaitu:

1. Tujuan Umum

a. Untuk memperbaiki pembelajaran sebelumnya pada mata pelajaran IPA sehingga hasil belajar siswa meningkat. 
b. Untuk memperbaiki kinerja guru sebagai peneliti, sehingga hasil belajar siswa meningkat.

c. Ikut berperan aktif dalam mengembangkan perubahan pembelajaran khususnya untuk mata pelajaran IPA.

2. Tujuan Khusus

Untuk meningkatkan prestasi belajar IPA dengan materi penggolongan hewan berdasarkan jenis makanan bagi siswa kelas IV SD N 3 Purwojati, UPK Purwojati Dinas Pendidikan Kabupaten Banyumas pada semester I Tahun Pelajaran 2015/ 2016.

\section{Kerangka Teori}

Sudjana (1990:22) prestasi belajar adalah kemampuan yang dimiliki siswa setelah ia menerima hasil belajaranya. Prestasi belajar ini dapat dilihat dari penguasaan siswa terhadap mata pelajaran yang ditempuhnya disekolah dengan cara tes yang disusun oleh guru. Berdasarkan pembahasan definisi belajar diatas terdapat ciri utama belajar yaitu proses perubahan perilaku dan pengalaman. Peneliti perlu menggunakan metode, model dan alat peraga yang bervariasi sebab setiap peserta didik memiliki tipe belajar yang berbeda. Tipe belajar auditif akan lebih mudah belajar malalui pendengaran, peserta didik yang memiliki tipe belajar visual akan lebih mudah belajar melalui penglihatan, sedangkan peserta didik yang memiliki belajar motorik akan lebih mudah belajar melalui perbuatan (Udin S. Winataputra dkk, 2006:2.16). Selain harus memperhatikan model, metode, alat peraga juga harus memperhatikan pribadi-pribadi peserta didik.

Pembelajaraan merupakan suatu proses penyampaian pengetahuan, yang dilaksanakan dengan menuangkan pengetahuan kepada siswa (Oemar Hamalik, 2008:25). Bila pembelajaran dipandang sebagai suatu proses, maka pembelajaran merupakan kegiatan guru dalam rangka membuat siswa belajar. Dari pendapat diatas dapat ditarik kesimpulan bahwa pembelajaran adalah suatu upaya kegiatan guru dalam rangka membuat siswa belajar untuk mempersiapkan diri siswa pada kehidupan yanag akan datang.

IPA adalah ilmu yang mempelajari peristiwa-peristiwa yang terjadi di alam (iskandar, 2001:2). Ilmu Pengetahuan Alam merupakan mata pelajaran di SD yang dimaksudkan agar siswa mempunyai pengetahuan, gagasan, dan konsep yang terorganisasi tentang alam di sekitarnya dengan melakukan observasi, eksperimentasi, penyimpulan dan penyusunan teori. Pada hakikatnya Ilmu Pengetahuan Alam sangat bermanfaat bagi kehidupan masyarakat.

Metode merupakan suatu model pembelajaran yang dilakukan guru dalam kegiatan belajar mengajar demi tercapainya suatu proses pembelajaran. Picture and picture adalah 
teknik mengajar dengan menggunakan media gambar. Untuk mempermudah pelaksanaan tindakan perlu disusun kerangka berfikir yang merupakan pelaksanaan penelitian tindakan kelas ini. Secara jelas dapat dilihat pada tabel 1 di bawah ini:

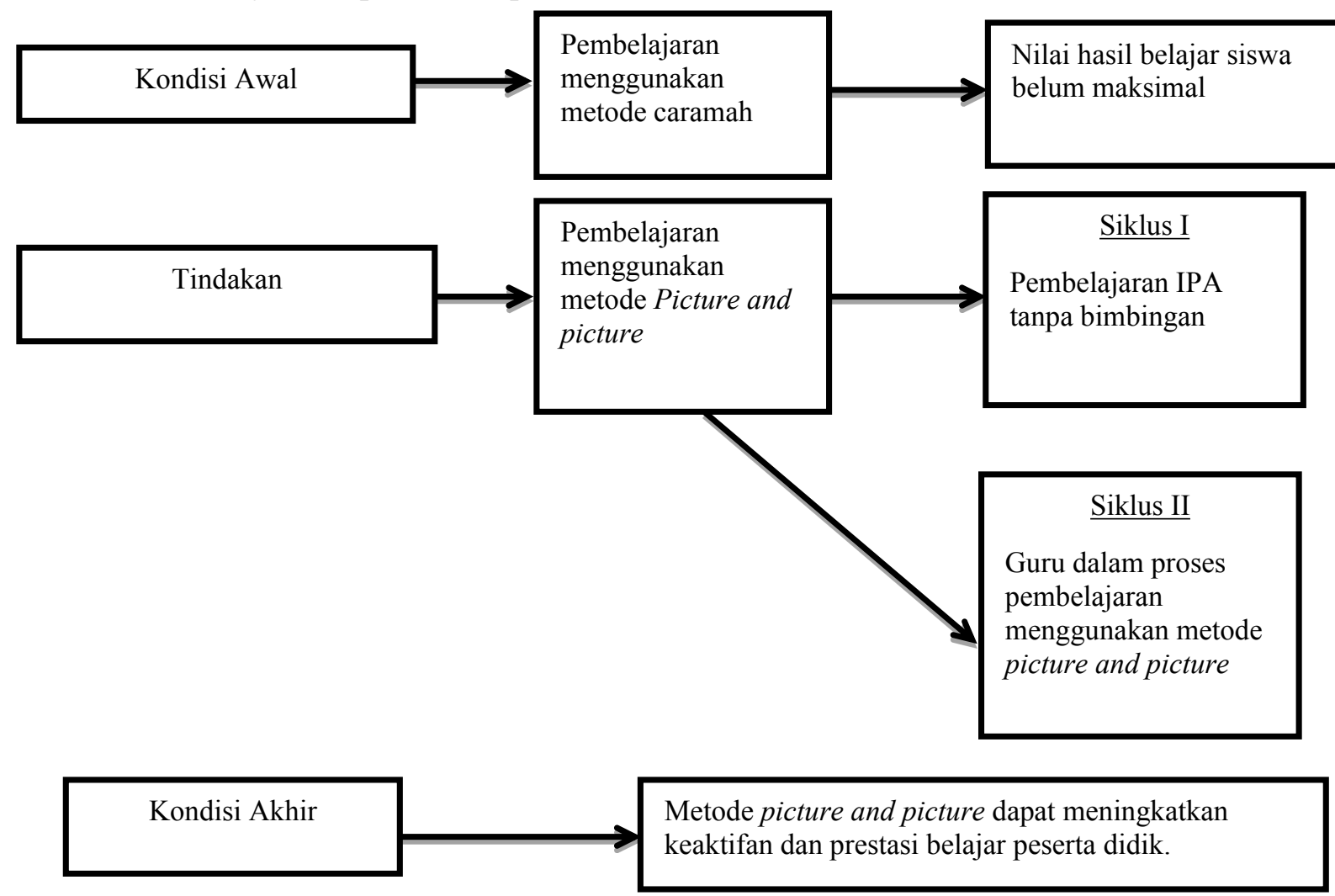

Gambar 1. Skema Kerangka Berpikir

\section{Metode}

\section{Desain Prosedur Perbaikan Pembelajaran}

Penelitian Tindakan Kelas adalah penelitian yang dilakukan oleh guru di dalam kelasnya sendiri, dengan tujuan untuk meningkatkan kinerjanya sebagai guru yang profesional sehingga hasil belajar semakin meningkat. Dengan melakukan Penelitian Tindakan Kelas kesalahan dalam proses belajar mengajar akan cepat teridentifikasi sehingga cepat pula diperbaiki dan kesalahan tersebut tidak akan berlanjut. 
Bagan Alur Proses Perbaikan

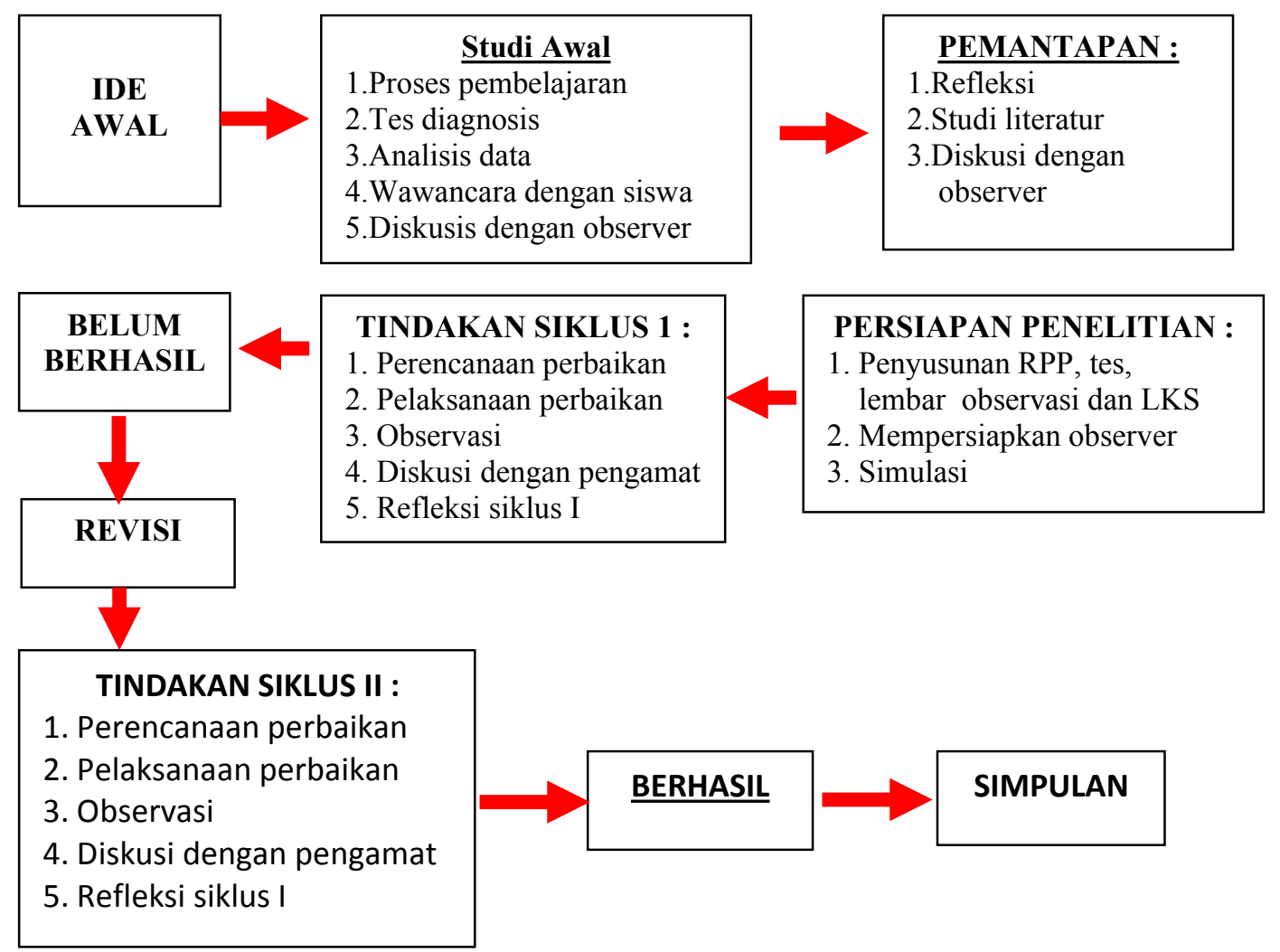

Gambar 2 Alur Penelitian Tindakan Kelas

Kegiatan Perbaikan Tiap Siklus

Mekanisme kerja Penelitian Tindakan Kelas diwujudkan dalam bentuk siklus, yang terdiri dari 2 siklus. Masing-masing siklus terdiri dari 4 kegiatan yaitu perencanaan, pelaksanaan, observasi dan refleksi.

\section{Hasil Penelitian dan Pembahasan}

Rekap keseluruhan Hasil belajar siswa sebagaimana di paparkan dalam tabel berikut.

Tabel 1. Rekap Keseluruhan Hasil Belajar Siswa

\begin{tabular}{|c|c|c|c|c|c|}
\hline \multirow{2}{*}{ NO } & \multirow{2}{*}{ Tahap } & \multicolumn{2}{|c|}{ Siswa tuntas } & \multicolumn{2}{c|}{ Siswa belum tuntas } \\
\cline { 3 - 6 } & & Frekuensi & Presentasi & Frekuensi & Presentasi \\
\hline 1 & Prasiklus & 3 & $16,7 \%$ & 15 & $83,3 \%$ \\
\hline 2 & Siklus I & 8 & $44,4 \%$ & 10 & $55,6 \%$ \\
\hline 3 & Siklus II & 16 & $88,8 \%$ & 2 & $11,2 \%$ \\
\hline
\end{tabular}




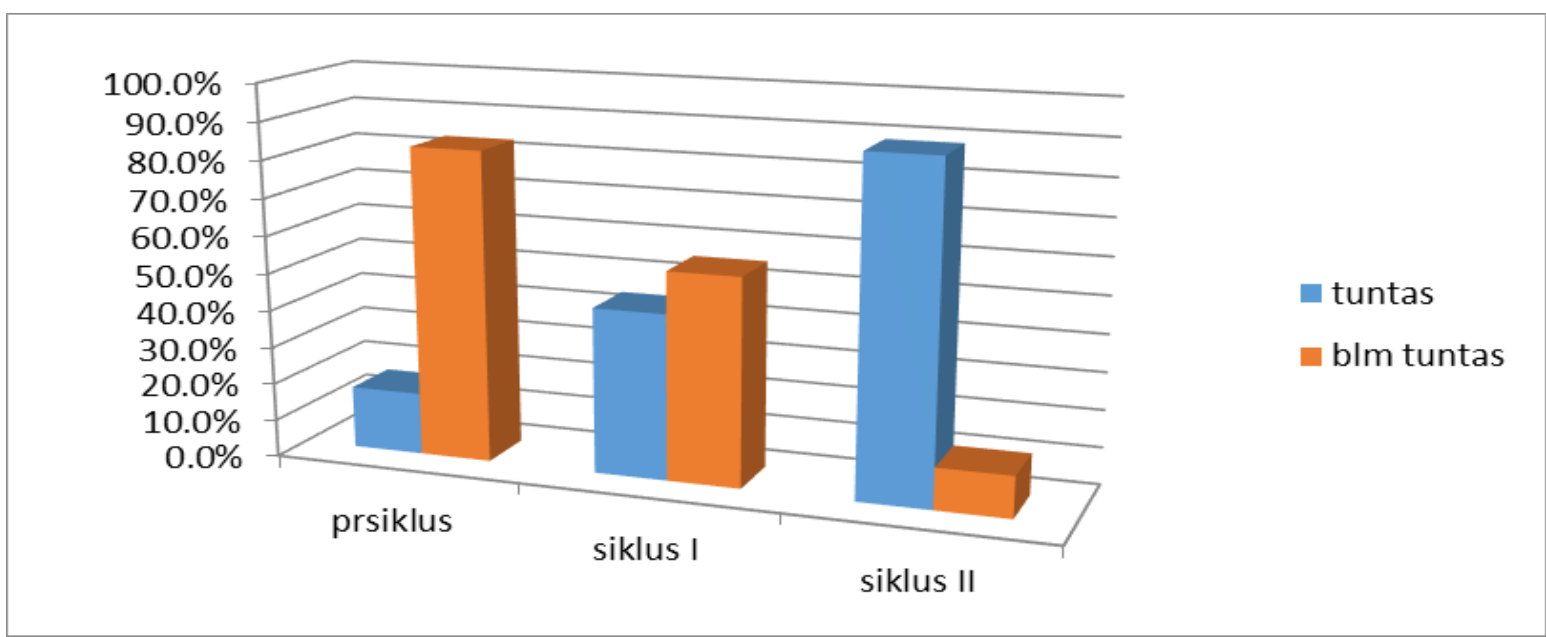

Gambar 2. Grafik prestasi belajar siswa pra siklus, siklus I, siklus II

Hasil Peningkatan keaktifan siswa

Tabel 2. Rekapitulasi Peningkatan Keaktifan Siswa

\begin{tabular}{|c|c|c|c|c|}
\hline \multirow{2}{*}{ No } & \multirow{2}{*}{ Skor } & \multicolumn{3}{|c|}{ Banyaknya Perolehan Skor Siswa } \\
\cline { 3 - 5 } & & Pra Siklus & Siklus I & Siklus II \\
\hline 1 & 5 & 0 & 6 & 11 \\
\hline 2 & 4 & 4 & 2 & 5 \\
\hline 3 & 3 & 8 & 6 & 2 \\
\hline 4 & 2 & 6 & 4 & 0 \\
\hline & Jumlah & 18 & 18 & 18 \\
\hline
\end{tabular}

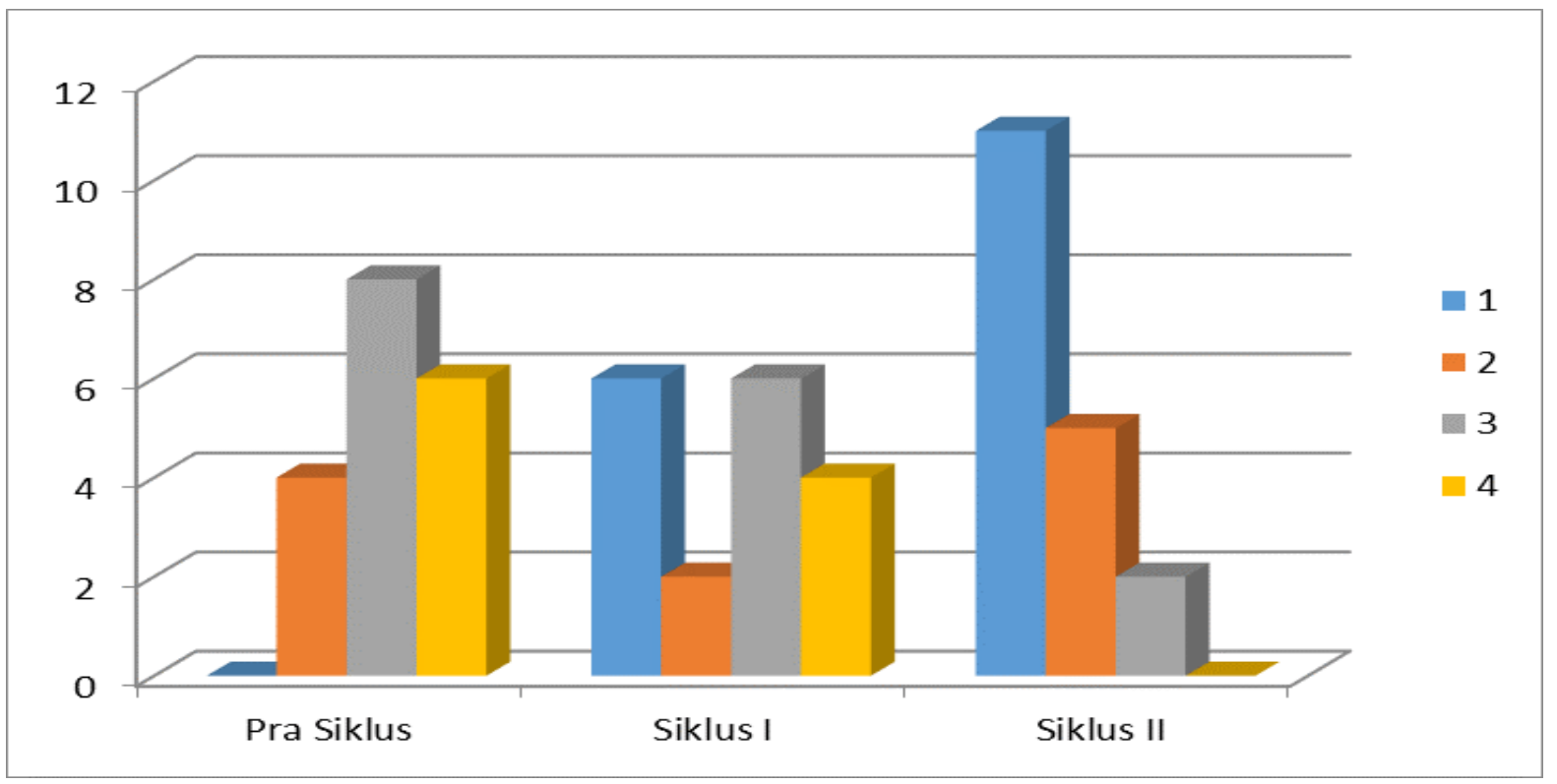

Gambar 3. Grafik Hasil Peningkatan Kektifan siswa 


\section{Pembahasan Hasil Penelitian Perbaikan Pembelajaran}

Pada studi awal terdapat $16,7 \%$ siswa yang tuntas belajarnya. Pada studi awal belum diperoleh hasil belajar sesuai dengan kriteria yang diharapkan, hal terebut karena peneliti belum menggunakan metode picture and picture dalam kegiatan pembelajaran. Pada siklus I diperoleh 44,4\% siswa yang tuntas belajarnya dan pada siklus ini keterlibatan siswa sudah menunjukan peningkatan. Sebab terjadinya peningkatan dikarenakan dalam pembelajaran siklus ini peneliti telah menerapkan metode picture and picture.

Penggunaan metode picture and picture sangat tepat untuk diterapkan karena dengan metode picture and picture meningkatkan keaktifan dan prestasi belajar siswa. Dengan metode picture and picture pada mata pelajaran IPA tentang penggolongan hewan berdasarkan jenis makanannya dapat membuat pembelajaran lebih mudah dan lebih cepat dalam menangkap isi pembelajaran adalah dengan metode picture and picture, diskusi kelompok, pengamatan, tanya jawab, dan pemberian ugas dapat peneliti laksanakan secara bertahap.

Pada perbaikan pembelajaran Siklus II terjadi peningkatan ketuntasan belajar dan peningkatan keakifan siswa dalam kegiatan pembelajaran, karena peneliti menggunakan metode picture and picture dan bimbingan pelajaran dari guru. Dengan metode picture and picture pada mata pelajaran IPA tentang penggolongan hewan berdasarkan jenis makanannya dapat membuat pembelajaran lebih mudah dan lebih cepat dalam menangkap isi pembelajaran adalah dengan metode picture and picture, diskusi kelompok, pengamatan, tanya jawab, dan pemberian tugas dapat peneliti laksanakan secara bertahap.

Model pembelajaran picture and picture dengan bimbingan guru dapat meningkatan prestasi belajar siswa dalam pembelajaran IPA materi penggolongan hewan berdasarkan jenis makanannya terbukti pada siklus II ini menunjukan prestasi belajar siswa kelas III SDN 3 Purwojati, Kecamatan Purwojati, Kabupaten Banyumas, meningkat dengan perolehan nilai rata-rata yaitu 81,4 . Dari data yang diperoleh siswa yang sudah mencapai kriteria 88,8\%, yang belum mencapai kriteria yang ditentukan hanya tinggal 11,2\% dari 18 siswa. Dengan demikian ketuntasan belajar sudah mencapai kriteria yang di harapkan.

\section{Simpulan}

Dari hasil penelitian tindakan kelas tentang penggunaan metode picture and picture pada matapelajaran IPA tentang materi pokok penggolongan hewan berdasarkan jenis 
makanan kelas IV SD Negeri 3 Purwojati, Kecamatan Purwojati, Kabupaten Banyumas, dapat peneliti simpulkan sebagai berikut :

1. Penerapan metode picture and picture pada mata pelajaran IPA tentang penggolongan jenis hewan berdasarkan makanan meningkatkan keaktifan belajar siswa kelas IV SDN 3 Purwojati, Kecamatan Purwojati, Kabupaten Banyumas, Tahun Pelajaran 2015/2016.

2. Penggunaan metode picture and picture pada mata pelajaran IPA tentang penggolongan hewan berdasarkan jenis makanan meningkatkan prestasi belajar siswa kelas IV SDN 3 Purwojati, Kecamatan Purwojati, Kabupaten Banyumas, Tahun Pelajaran 2015/2016, yaitu pada pra siklus terdapat 3 siswa dari 18 siswa yang tuntas belajarnya $(16,7 \%)$ dan yang belum tuntas terdapat 15 siswa dari 8 siswa (83,3\%); pada siklus I terdapat 8 siswa dari 18 siswa yang tuntas belajarnya $(44,4 \%)$ dan yang belum tuntas belajarnya terdapat 10 siswa dari 8 siswa(55,6\%); pada siklus II terdapat 16 siswa dari 18 siswa yang tuntas belajarnya $(88,8 \%)$ dan yang belum tuntas belajarnya terdapat 2 siswa dari 18 siswa $(11,2 \%)$.

\section{Saran Tindak Lanjut}

Berdasarkan upaya diatas dalam upaya perbaikan pembelajaran, maka ada beberapa saran tindak lanjut yang perlu terus dilakukan yaitu:

a. Penelitian ini dapat dipakai untuk pembelajaran di sekolah-sekolah guna meningkatkan prestasi belajar siswa.

b. Bagi peneliti berikutnya, penelitian ini dapat dipakai sebagai acuan dalam mempersiapkan pembelajaran.

c. Bagi seorang guru penelitian ini dapat dipakai untuk memperbaiki kinerja guru sehingga benar-benar bisa menjadi seorang guru yang profesional.

Peneliti telah merasakan secara langsung manfaat dari penilitian tindakan kelas ini, meskipun belum sempurna. Pada kesempatan lain, peneliti berharap dapat melakukan penelitian lain yang lebih baik untuk beberapa pembelajaran yang mengalami kendala pencapaian ketuntasan belajar. Kekurangan peneliti menguasai beberapa inovasi pembelajaran menghambat perbaikan pembelajaran. Pada kesempatan lain peneliti akan berusaha menambah pengetahuan dengan membaca dan berkonsultasi dengan teman sejawat. 


\section{Daftar Pustaka}

Abdurrahman, Mulyono. (2003). Pendidikan Bagi Anak Berkesulitan Belajar. Jakarta: Rineka Cipta.

Belly, Ellya dkk. 2006. Pengaruh Motivasi terhadap Minat Mahasiswa Akuntasi. Simposium Nasional Akuntasi 9 Padang.

Bob dan Anik Anwar. 1983. Pedoman Pelaksanaan Menuju Pra Seleksi Murni. Bandung : Ganesa Exact.

Dimyati dan Mujiono. (2006). Belajar dan Pembelajaran. Jakarta: Rineka Cipta.

Mulyono M. 2009. Pendidikan Bagi Anak yang Berkesulitan Belajar. Jakarta : Rineka Cipta.

Mustaqim Burhan, Astuty Ary. 2008. Ayo Belajar Matematika untuk SD dan MI Kelas IV. Pusat Perbukuan Departemen Pendidikan.

Nasoetion, Andi Hakim. 1980. Landasan Matematika. Jakarta : Bharata Aksara.

Oemar Hamalik. 1993. Metode Mengajar dan Kesulitan-kesulitan Belajar. Bandung : Tarsito.

Suciati, Durri Andriani. 1997. Metode Penelitian. Jakarta : Universitas terbuka.

Sudjana, Nana. 2009. Dasar-dasar Proses Belajar Mengajar. Bandung : Sinar Baru Algensindo.

Suharsimi Arikunto. (1993). Penelitian Tindakan Kelas (PTK). Jakarta: Departemen Pendidikan dan Kebudayaan.

Suharsimi Arikunto. 1999. Prosedur Penelitian Suatu Pendekatan Politik. Jakarta Rineka Cipta.

Tim FKIP. 2013. Pemantapan Kemampuan Profesional, cet I. Tangerang Selatan : Universitas terbuka.

Tim Penyusun Kamus Pusat dan Pengembangan Bahan. 1994. Kamus Besar Indonesia. Jakarta : Balai Pustaka.

Winataputra Udin S, dkk. 2006. Strategi Belajar Mengajar cet. 19. Jakarta : Universitas terbuka. 